\title{
Assessing the Agricultural Sector Vulnerability to Climate Change in Sri Lanka: Developing an Agricultural Vulnerability Index
}

\author{
W.C.S.M. Abeysekara ${ }^{1,2}$, M. Siriwardana ${ }^{1}$ and S. Meng ${ }^{1}$
}

\begin{abstract}
This study developed a set of composite indices to analyse the vulnerability to climate change of the agricultural sector in Sri Lanka using the data between 2001 and 2018. The aim was to identify the level of vulnerability of the agricultural sector to climate risks at the country level, as a tool to better understand the variability and magnitude of impacts and adaptive capacities required to overcome the risks due to climate change. To calculate the indices, environmental and socio-economic indicators representing the conceptual components of vulnerability, namely, exposure, sensitivity, and adaptive capacity were selected based on previous studies. Secondary data were collected for the selected indicators and normalised considering the indicator's functional relationship to vulnerability. Normalised data were then weighted and aggregated using two weighting methods and two aggregation methods to calculate four vulnerability indices, in order to minimize the impact of the known limitations of the methodological approaches to create composite indices. The values for composite indices were standardised to the range 0-1 and divided into five levels of vulnerability based on equal intervals, which revealed a moderate level of agricultural vulnerability to climate change over the eighteen-year study period. The multidimensional assessment, further, revealed the upward trend of vulnerability due to the increased sensitivity of the system to climate change. Even though the adaptive capacity of the country has been strengthened in the recent past, it has a critical role to play in mitigating vulnerability. The study also suggests methods for predicting future vulnerability by replicating the calculations.
\end{abstract}

Keywords: Climate change, Agriculture, Vulnerability, Index, Adaptation

\footnotetext{
${ }^{1}$ University of New England, Australia.

${ }^{2}$ University of Ruhuna, Sri Lanka.
} 


\section{Introduction}

The whole world is confronted by the momentous challenges of climate change, the impacts of which are unevenly distributed across the planet. The means to cope with changing climate also varies substantially across countries, sectors, and communities, as resources and wealth are also unevenly distributed. Understanding the factors variability and magnitude of impact is required, to identify potential adaption methods and to decide coping strategies. As noted by Handmer et al. (1999), the study of adaptation should begin with assessing its vulnerability to climate change. The vulnerability and exposure to the pre cent changes in the climate should be reduced as the first step towards adaptation (IPCC, 2014a).

Scholars have been repeatedly demonstrated diverse approaches for vulnerability assessments (Janssen et al., 2006). However, the traditional vulnerability assessment methods have only considered the factors and stressors, and thereby its adverse impacts without considering its adaptive capacity, ignoring the fact that societies or individuals develop coping mechanisms to bounce back from these shocks (Ribot, 1995, Füssel and Klein, 2006). Simply, vulnerability and adaptation can be explained as two facets of the same coin. Working group II of the intergovernmental panel on climate change (IPCC) in its fifth assessment report defines vulnerability as the tendency to be adversely affected due to its sensitivity or lower ability to bounce back from shocks. The third assessment report of the IPCC defines vulnerability as a function of exposure, sensitivity, and adaptive capacity (McCarthy et al., 2001). Following McCarthy et al. (2001), most of the current vulnerability studies show a shift towards more comprehensive vulnerability assessments which address vulnerability as a function of three components; exposure, sensitivity, and adaptive capacity (Füssel and Klein, 2006). These types of vulnerability assessment identifies both vulnerable systems and the causes of vulnerability (Luers et al., 2003). Janssen et al. (2006) observed that many vulnerability assessments constitute comparative assessments of case studies with less emphasis on mathematical conceptual analysis. Alternatively, Ionescu et al. (2009) highlighted the importance of focusing on mathematical models to investigate vulnerability. It has been increasingly argued that quantifying vulnerability is complex, if not impossible. This may be due to uncertainty in defining vulnerability (Ionescu et al., 2009); that it is an unobservable phenomenon (Luers et al., 2003); and that it is influenced by a range of social, economic, and cultural factors and processes (IPCC, 2014a). Nonetheless, several quantification studies exist (Ribot, 1995; Schimmelpfennig and Yohe, 1999; Stephen and Downing, 2001; Luers et al., 2003; Ionescu et al., 
2009; Shah et al., 2013; Krishnamurthy et al., 2014; Wiréhn et al., 2015). Gbetibouo et al. (2010) classified these quantification studies as either econometric or indicator approaches. Among the latter group, developing a composite index is the most common approach.

The first step in developing a composite index is in deciding which phenomena are to be measured and selecting the study area. Even though climate change affects all sectors of the economy and strata in the community, the magnitude of the impact will vary according to sensitivity and adaptive capacity. The Conference of the Parties to the United Nations Framework Convention on Climate Change (UNFCCC), in its sixteenth session held in Cancun in December 2010, reported that the least developed countries and small island developing states are most vulnerable to climate change (Kyoto Protocol, 1997). McCarthy et al. (2001) and IPCC (2014b) have asserted that developing countries are more vulnerable, in that they have less capacity to adapt.

As a small island and a developing nation, Sri Lanka should make every effort to adapt and reduce the impacts of climate change, particularly given its ranking among the six most seriously affected countries on the Global Climate Risk Index of 2018 (Eckstein et al., 2019). Watson (2000) reveals that certain socio-economic sectors such as agriculture, forestry and fisheries are more vulnerable to climate change than others. Productivity in the agricultural sector is highly dependent on climatic and environmental factors. Climate Changes can directly or indirectly impact on some components in agriculture, such as water availability and level of production (Wiréhn et al., 2015). Having identified agriculture as an extremely vulnerable economic sector, many research studies have assessed national and regional levels of vulnerability and proposed possible adaptation strategies (Brisson et al., 2003; Luers et al., 2003; o'Brien et al., 2004; Gbetibouo et al., 2010; Wiréhn et al., 2015). Thus, the main objective of this study is to evaluate the levels of agricultural vulnerability to climate change in Sri Lanka over the past eighteen years as the first step towards deciding future adaptation strategies. Developing vulnerability indices is one of the common approaches used by many researchers in similar studies.

Vulnerability indices comprise a set of indicators, which represent the multidimensional components of vulnerability. These indicators are then combined mathematically into a single index value, which provides an estimation of the overall vulnerability of the studied system and is more worthwhile than analysing the trends of single indicators (Saisana and Tarantola, 2002). These data-driven vulnerability assessments also enable policymakers to spot specific 
problems, identify trends over the period, and highlight policy successes and failures to prioritize and optimize the gains from investments in climate change adaptation strategies (Saisana and Tarantola, 2002; Shah et al., 2013). The indexed results enable territory-wise comparisons and will attract public interest due to their simplicity (Saisana and Tarantola, 2002).

When constructing a composite index, an analyst should make several judgments in the selection of indicators, their weightings, and treatment of missing data (Saisana and Tarantola, 2002). Researchers may use a deductive or inductive approach in selecting indicators (Adger et al., 2005). The selection of indicators using a deductive approach is based on theories that explain their functional relationship. The inductive methods involve relating variables to vulnerability components using a statistical approach (Eriksen and Kelly, 2007). Eriksen and Kelly (2007) add that many researchers apply indicators derived from previous vulnerability studies and that numerous methodological assumptions are made in the aggregation and weighting of indicators. Past studies have generally used three weighting methods in developing composite indices: (1) arbitrary choice of equal weight (o'Brien et al., 2004; Lucas and Hilderink, 2005; Krishnamurthy et al., 2014); (2) expert judgment (Vincent, 2004; Brooks et al., 2005); and (3) statistical approaches such as principal component analysis (PCA) (Saisana and Tarantola, 2002; Nardo et al., 2005; Gbetibouo et al., 2010). It has been argued that assigning equal weightage is too subjective (Hebb and Mortsch, 2007; Eakin and Bojorquez-Tapia, 2008) and that there are complications in expert judgments such as levels of agreement between individual experts, as well as their lack of expertise in some study areas (Nardo et al., 2005; Cutter and Finch, 2008; Gbetibouo et al., 2010). The majority of research faces a fundamental difficulty in collecting appropriate data and the unavailability of important data, and missing data in a time series inevitably leads to prejudice in the selection of indicators (Vincent, 2004). This paper uses two weighting methods and two aggregation methods to calculate four vulnerability indices, with the objective of minimizing the bias of these methodological approaches to create composite indices and to compare these approaches.

The number of scientific publications related to climate change has doubled between 2005 and 2010. However, only 8101 out of 36,198 climate change-related publications cover Asia in that period (IPCC, 2014b) and few climate change assessments cover Sri Lanka. Based on this minimal coverage, this paper also aims to contribute to the climate change literature on Sri Lanka, by providing a country-level analysis on 
agricultural vulnerability and by developing an agricultural vulnerability index. Like other countries, Sri Lanka uses performance metrics to measure policy outcomes in economics, education, and other socioeconomic areas. Therefore, it is natural to extend this practice to the climate change challenge.

The outline of the paper is as follows. The next section, the first part describes the rationale for indicator selection; classification according to the three vulnerability components, namely, exposure, sensitivity, and adaptive capacity; and decisions regarding their functional relationship with vulnerability, based on an in-depth review of similar indices. The second section discusses the various methods used in the different stages of vulnerability index calculation. The third section presents and interprets the results. The final section provides a conclusion in which some limitations and suggestions for further improvement of the index and future studies are outlined.

\section{Methodology}

This study used three main steps to develop a composite index to assess agricultural vulnerability to climate change in Sri Lanka. These steps comprised: the choice of indicators based on an in-depth literature review and availability of quality data; the index calculation by normalizing the data set and assigning proper weights to the indicators; and finally presenting and interpreting the results.

\section{Choice of Indicators}

Many climate-related vulnerability assessments have relied on IPCC working definitions on vulnerability (Luers et al., 2003; o'Brien et al., 2004; Hahn et al., 2009; Gbetibouo et al., 2010; Krishnamurthy et al., 2014; Wiréhn et al., 2015). The framework of analysis for this study is based on the following IPCC working definition on vulnerability: "The degree to which a system is susceptible to, or unable to cope with, adverse effects of climate change, including climate variability and extremes", and the definition of Working Group II of the IPCC fifth assessment report: "The propensity of a system to be adversely affected due to changes in the climatic conditions and lack of ability to bounce back from shocks and adapt" (IPCC, 2014b). "Vulnerability is a function of the character, magnitude, and rate of climate variation to which a system is exposed, its sensitivity, and its adaptive capacity" (IPCC, 2001; IPCC, 2007).

\section{Vulnerability $=f($ Exposure; Sensitivity; Adaptive capacity $)$}


Many climate change-related vulnerability indices have used similar indicators. However, due to variations in interpretation of the terms "exposure", "sensitivity" and "adaptive capacity", analysts categorise the same indicator into different sub-indices (Table 1). For example, Wiréhn et al. (2015) categorised soil organic matter, amount of phosphorus, and $\mathrm{pH}$ value as sensitivity indicators, while o'Brien et al. (2004) categorised soil condition as an indicator of adaptive capacity. Similarly, Gbetibouo et al. (2010) used the land degradation index as a sensitivity indicator, while o'Brien et al. (2004) used severity of soil degradation as an adaptive capacity indicator of adaptive capacity.

\section{Table 1: Indicators used by the reviewed studies}

\begin{tabular}{|c|c|c|}
\hline Exposure & Sensitivity & Adaptive Capacity \\
\hline $\begin{array}{l}\text { Change in } \\
\text { temperature }\end{array}$ & $\%$ Irrigated land $^{1,2 * 3,5}$ & Farm organisation $^{1}$ \\
\hline $\begin{array}{l}\text { Change in } \\
\text { precipitation } \\
\text { 1,2,3,5 }\end{array}$ & $\begin{array}{l}\% \text { rain fed agricultural } \\
\text { land }^{4,5}\end{array}$ & Literacy rate re $^{1,2}$ \\
\hline \multirow{6}{*}{$\begin{array}{l}\text { Occurrence of } \\
\text { extreme climate } \\
\text { events } \\
1,2^{*}, 3,4\end{array}$} & $\begin{array}{l}\text { Land degradation } \\
\text { index } x^{1,2^{*}}\end{array}$ & Farm income $e^{1,3}$ \\
\hline & $\begin{array}{l}\text { Soil condition }(\mathrm{pH} \text {, } \\
\text { Organic matter, } \\
\text { Phosphorous, } \\
\text { Erosion })^{3,2^{*}}\end{array}$ & $\begin{array}{l}\% \text { People below } \\
\text { poverty line } e^{1,4}\end{array}$ \\
\hline & $\begin{array}{l}\% \text { Small scale } \\
\text { farms } s^{1,2 * 3,5}\end{array}$ & $\begin{array}{l}\% \text { Agriculture } \\
\text { GDP }^{1}\end{array}$ \\
\hline & $\begin{array}{l}\text { Rural population } \\
\text { density }\end{array}$ & Farm assets $^{1}$ \\
\hline & $\begin{array}{l}\text { Crop diversification } \\
\text { index }\end{array}$ & Access to credit ${ }^{1}$ \\
\hline & $\%$ of arable land ${ }^{3}$ & $\begin{array}{l}\text { Infrastructure } \\
\text { index }\end{array}$ \\
\hline
\end{tabular}


Table 1 contd...: Indicators used by the reviewed studies

\begin{tabular}{|c|c|c|}
\hline Exposure & Sensitivity & Adaptive Capacity \\
\hline & $\begin{array}{l}\text { Ground water } \\
\text { availability }{ }^{2 *, 3,5}\end{array}$ & Dependency ratio ${ }^{3}$ \\
\hline & $\begin{array}{l}\text { Employment in } \\
\text { agriculture }(\% \text { of } \\
\text { employment })^{2^{*}, 3}\end{array}$ & $\begin{array}{l}\text { Unemployment } \\
\text { rate }^{3}\end{array}$ \\
\hline & $\%$ of forest cover ${ }^{4}$ & $\begin{array}{l}\text { Fertilizer } \\
\text { consumed }^{3,5}\end{array}$ \\
\hline & Population density 3 & Mean crop yield ${ }^{3,4,5}$ \\
\hline & & $\begin{array}{l}\text { Area under high } \\
\text { yielding varieties }\end{array}$ \\
\hline
\end{tabular}

Notes: ${ }^{1}$ (Gbetibouo et al., 2010), ${ }^{2}$ (o'Brien et al., 2004), ${ }^{3}$ (Wiréhn et al., 2015), ${ }^{4}$ (Krishnamurthy et al., 2014), ${ }^{5}$ (Ravindranath et al., 2011), *Used in a different component of vulnerability (exposure, sensitivity, adaptive capacity)

Thus, an in-depth literature review was conducted to select appropriate variables for this study. The rationale for including the selected variables follows:

\section{Exposure}

Exposure is an external dimension of vulnerability which represents the degree to which a system is exposed to climate variations (Füssel and Klein, 2006). IPCC (2007) define exposure as "the nature and the degree to which a system is exposed to significant climatic variations". Due to climatic variations in precipitation and temperature, and a higher frequency of extreme events such as floods, droughts and landslides, farmers face many new and unfamiliar challenges which make the farming community more vulnerable (Goodman et al., 1997; Gbetibouo et al., 2010).

Most climate change assessments have used variations in mean annual temperature and mean annual precipitation as two variables impacting on exposure (o'Brien et al., 2004; Füssel and Klein, 2006; Gbetibouo et al., 2010; Shah et al., 2013; Wiréhn et al., 2015). According to Gbetibouo et al. (2010), researchers should attach greater importance to adjusting excessive variations in precipitation and 
temperature. They explain the risk of higher temperature and reduced precipitation as having a negative impact on agricultural production in leading to a hotter climate and water scarcity (Gbetibouo et al., 2010). Lobell and Burke (2008) demonstrated that a change in precipitation by one standard deviation could result in a $10 \%$ loss in crop production. Hence, the changes in mean annual temperature and precipitation are directly proportional to vulnerability.

Higher frequencies of the occurrence of extreme events make countries more vulnerable. Globally, vast amounts of agricultural land are increasingly exposed to drought and flood events which will lead to food insecurity (Krishnamurthy et al., 2014). Extreme events can cause major crop losses (Falloon and Betts, 2010) and lead to such indirect impacts as nutrient losses (Nuñez, 2005), soil erosion, and land degradation (Clarke and Rendell, 2010). Therefore, it is assumed that more frequent extreme events have a positive functional relationship with agricultural vulnerability.

\section{Sensitivity}

Sensitivity is referred to as a measurement of system responsiveness to a particular climate stimulus. This impact or response could be either positive or negative (Olmos, 2001; o'Brien et al., 2004). Füssel and Klein (2006) interpret sensitivity as an internal dimension of vulnerability in a system. The current study has selected sensitivity indicators representing environmental and human parameters.

Forest (Brooks et al., 2005; Krishnamurthy et al., 2014), arable land (Wiréhn et al., 2015) and paddy-field areas served by major irrigation schemes, irrigation rate (Gbetibouo et al., 2010), irrigated land area (Wiréhn et al., 2015) are considered environmental indicators. Climate regulation is a major ecosystem service provided by forests (Bonan, 1993; Hansen et al., 2013). Forests also act directly as physical barriers to some extreme climate events and indirectly reduce land degradation (Dale et al., 2001). Forests also diminish the impact of global warming providing an evaporative cooling mechanism (Bonan, 1993) and, therefore, the responsiveness of forest cover to climatic stimuli reduces the vulnerability of a system indicating a negative functional relationship. The study of Zhang and Cai (2011) illustrates the sensitivity of global agricultural and available arable land to climate change. Land under crops is highly sensitive to climate change and, therefore, arable land area has a positive functional relationship with vulnerability (Wiréhn et al., 2015). However, many research studies show that irrigated agricultural lands are less sensitive to climate change 
than rain-fed agricultural lands (o'Brien et al., 2004; Gbetibouo et al., 2010; Masia et al., 2018). Higher irrigation capacities reduce the sensitivity to precipitation changes. Therefore, the amount of irrigated agricultural lands is inversely proportional to vulnerability.

The percentage of the rural population (Vincent, 2004; Brooks et al., 2005; Gbetibouo and Hassan, 2005; Gbetibouo et al., 2010), population density (Brooks et al., 2005; Wiréhn et al., 2015), mid-year population, and employment in agriculture (Brooks et al., 2005; Hahn et al., 2009; Shah et al., 2013; Wiréhn et al., 2015) represent the human component. According to Vincent (2004), the percentage of rural population and vulnerability has a positive functional relationship as the majority of the rural population depends on natural resources (IPCC, 2014b). Population density indicates the portion of the population potentially more vulnerable to natural disasters (Hegglin and Huggel, 2008; Yusuf and Francisco, 2009). Areas with greater population density are more sensitive to climate hazards than less dense areas (Gbetibouo et al., 2010). Therefore, the percentages of the rural population and population density show a positive functional relationship with vulnerability (IPCC, 2014a). Increasing population intensifies the impact of climate change on agriculture (Zhang and Cai, 2011), increasing the demand for scarce natural resources, and adding to the burden on the agricultural sector to feed the growing population. In short, increasing population increases the level of vulnerability. It may be generalised that people who depend on climate-sensitive livelihoods are more vulnerable to climate change. Olsson et al. (2014) state that agricultural livelihoods are directly climate-sensitive. Hence, this variable is directly proportional to climate change.

\section{Adaptive Capacity}

Adaptive capacity is defined as the potential or capability of a system, region or community to adapt (adjust) to climate stimuli (IPCC, 2001; IPCC, 2007; IPCC, 2014b). Füssel and Klein (2006) categorised adaptive capacity as an internal dimension that can decrease the sensitivity of an exposed area to climate change. However, non-climatic indicators of adaptive capacity have no potential to directly reduce the exposure, sensitivity, and thereby the impact (Wiréhn et al., 2015). Nevertheless, they jointly strengthen the asset portfolio which is the key determinant of adaptive capacity (Gbetibouo et al., 2010). The greater the asset ownership, the greater the adaptive capacity and, conversely, the lesser the access to assets, the greater their insecurity (Moser and Satterthwaite, 2010). Hence, the concept of vulnerability is linked to livelihood assets (Wiréhn et al., 2015). 
The literacy rate and the number of university graduates in agricultural disciplines consider as human capital. The ability to access and process information is enhanced by superior literacy rates, thus, boosting adaptive capacity (Brenkert and Malone, 2005; Brooks et al., 2005). Therefore, literacy rate and adaptive capacity have a positive functional relationship. According to Pratley (2008), the viability of the agricultural sector is dependent on ongoing research and development studies which lead to innovation and invention. The author further emphasized the important contribution of agricultural graduates in this regard (Pratley, 2008). Therefore, the human capital of agricultural graduates enhances the national adaptive capacity (Brenkert and Malone, 2005).

Financial capital is represented by GDP per capita, poverty headcount, cost of production, crop production index, unemployment rate, and access to credit. The higher the values of per capita GDP, crop production, and access to credit, the wealthier the people (Gbetibouo et al., 2010). Wealth enhances access to markets, technology, and other resources that improve the adaptive capacity (Brenkert and Malone, $2005)$. Hence, these variables are inversely proportional to vulnerability (Gbetibouo et al., 2010; Wiréhn et al., 2015). Poverty, production costs, and unemployment, however, reduce the ability to access financial capital. Handmer et al. (1999) posit that poverty restricts adaption to climate change. Unemployment and increased production costs also enhance population or community susceptibility to variability in climate events.

Infrastructure facilities and fertilizer usage will access physical capital and increase the adaptive capacity (Adger et al., 2005; IPCC, 2007; Gbetibouo et al., 2010; Wiréhn et al., 2015). Conversely, the dependency ratio which indicates the ratio of economically inactive people to economically active people reduces the adaptive capacity. Higher the dependency ratio, lower the adaptive capacity (Brenkert and Malone, 2005).

\section{Table 2: Selected indicators for vulnerability index}

\begin{tabular}{llll}
\hline $\begin{array}{l}\text { Vulnerability } \\
\text { component }\end{array}$ & Indicator & $\begin{array}{l}\text { Functional } \\
\text { relationship }\end{array}$ & Source \\
\hline Exposure & $\begin{array}{l}\text { Annual } \\
\text { temperature and } \\
\text { precipitation } \\
\text { change }\end{array}$ & + & $\begin{array}{l}\text { Department of } \\
\text { Meteorology - Sri Lanka }\end{array}$ \\
\hline
\end{tabular}


Table 2 contd...: Selected indicators for vulnerability index

\begin{tabular}{|c|c|c|c|}
\hline $\begin{array}{l}\text { Vulnerability } \\
\text { component }\end{array}$ & Indicator & $\begin{array}{l}\text { Functional } \\
\text { relationship }\end{array}$ & Source \\
\hline Exposure & $\begin{array}{l}\text { Frequency of } \\
\text { occurrence of } \\
\text { extreme events } \\
\text { (Floods, drought, } \\
\text { landslides) }\end{array}$ & + & $\begin{array}{l}\text { Disaster Management } \\
\text { Centre - Sri Lanka }\end{array}$ \\
\hline \multirow{6}{*}{ Sensitivity } & $\begin{array}{l}\text { Arable lands / } \\
\text { Percentage of } \\
\text { agricultural lands }\end{array}$ & + & $\begin{array}{l}\text { World Bank - } \\
\text { Development indicators }\end{array}$ \\
\hline & Forest area & - & $\begin{array}{l}\text { World Bank - } \\
\text { Development indicators }\end{array}$ \\
\hline & $\begin{array}{l}\text { Percentage of the } \\
\text { rural population }\end{array}$ & + & $\begin{array}{l}\text { World Bank - } \\
\text { Development indicators }\end{array}$ \\
\hline & $\begin{array}{l}\text { Mid-year } \\
\text { population/ } \\
\text { population density }\end{array}$ & + & $\begin{array}{l}\text { Various issues of annual } \\
\text { reports Central Bank of Sri } \\
\text { Lanka }\end{array}$ \\
\hline & $\begin{array}{l}\text { Employment in } \\
\text { agriculture ( } \% \text { of } \\
\text { employment) }\end{array}$ & + & $\begin{array}{l}\text { Various issues of annual } \\
\text { reports Central Bank of Sri } \\
\text { Lanka }\end{array}$ \\
\hline & $\begin{array}{l}\text { Irrigated extent of } \\
\text { paddy land }\end{array}$ & - & $\begin{array}{l}\text { Department of Census and } \\
\text { Statistics Sri Lanka }\end{array}$ \\
\hline \multirow{4}{*}{$\begin{array}{l}\text { Adaptive } \\
\text { Capacity }\end{array}$} & $\begin{array}{l}\text { Labour force } \\
\text { unemployed }\end{array}$ & + & $\begin{array}{l}\text { Various issues of annual } \\
\text { reports Central Bank of Sri } \\
\text { Lanka }\end{array}$ \\
\hline & GDP per capita & - & $\begin{array}{l}\text { Various issues of annual } \\
\text { reports Central Bank of Sri } \\
\text { Lanka }\end{array}$ \\
\hline & $\begin{array}{l}\text { Age dependency } \\
\text { ratio ( } \% \text { of } \\
\text { working-age } \\
\text { population) }\end{array}$ & + & $\begin{array}{l}\text { Various issues of annual } \\
\text { reports Central Bank of Sri } \\
\text { Lanka }\end{array}$ \\
\hline & $\begin{array}{l}\text { Poverty } \\
\text { headcount }\end{array}$ & + & $\begin{array}{l}\text { Various issues of annual } \\
\text { reports Central Bank of Sri } \\
\text { Lanka }\end{array}$ \\
\hline
\end{tabular}


Table 2 contd...: Selected indicators for vulnerability index

\begin{tabular}{|c|c|c|c|}
\hline $\begin{array}{l}\text { Vulnerability } \\
\text { component }\end{array}$ & Indicator & $\begin{array}{l}\text { Functional } \\
\text { relationship }\end{array}$ & Source \\
\hline \multirow{6}{*}{$\begin{array}{l}\text { Adaptive } \\
\text { Capacity }\end{array}$} & Literacy rate & - & $\begin{array}{l}\text { Various issues of annual } \\
\text { reports Central Bank of Sri } \\
\text { Lanka }\end{array}$ \\
\hline & $\begin{array}{l}\text { No. of University } \\
\text { Students } \\
\text { Graduated - } \\
\text { Agriculture } \\
\text { (B.Sc.) }\end{array}$ & - & Central Bank of Sri Lanka \\
\hline & $\begin{array}{l}\text { Infrastructure } \\
\text { index }\end{array}$ & - & $\begin{array}{l}\text { Based on data obtained } \\
\text { from the Central Bank of } \\
\text { Sri Lanka and the } \\
\text { Department of Census and } \\
\text { Statistics Sri Lanka }\end{array}$ \\
\hline & $\begin{array}{l}\text { Crop production } \\
\text { Index }\end{array}$ & - & $\begin{array}{l}\text { World Bank - } \\
\text { Development indicators }\end{array}$ \\
\hline & $\begin{array}{l}\text { Fertilizer } \\
\text { consumption } \\
\text { (kilograms per } \\
\text { hectare of arable } \\
\text { land) }\end{array}$ & - & $\begin{array}{l}\text { World Bank - } \\
\text { Development indicators }\end{array}$ \\
\hline & $\begin{array}{l}\text { Cost of } \\
\text { production of } \\
\text { various crops }\end{array}$ & + & $\begin{array}{l}\text { Various issues of annual } \\
\text { reports Central Bank of Sri } \\
\text { Lanka }\end{array}$ \\
\hline
\end{tabular}

\section{Index Calculation}

Having selected the appropriate variables and identified the functional relationships to captured agricultural vulnerability to climate change (Table 2), the next step is data collection. Data representing the selected variables were collected for the period 2001 to 2018 Data were normalized to facilitate the comparison of variables measured in different scales and units. Indicators were normalized to the range between 0 and 1, based on the method used by the United Nations Development Program (UNDP) in constructing the Human Development Index (HDI).

If the selected indicator has a positive functional relationship with vulnerability and, therefore vulnerability rises with an increasing value of the variable, normalisation was performed using the following equation equation (1), 


$$
X_{t j}=\frac{Y_{t j}-\operatorname{Min} X_{j}}{\operatorname{Max} X_{j}-\operatorname{Min} X_{j}}
$$

Where, $X t j$ is the normalised value of the indicator $(j)$ with respect to year (t), $Y_{t j}$ is the actual value of the indicator $(\mathrm{j})$ with respect to year (t), Min $X j$ and $\operatorname{Max} X j$ are the minimum and maximum values, respectively, of indicator $(j)$ in the time series.

If vulnerability decreases with an increase in the value of the indicator, the functional relationship with vulnerability is negative, and the following equation was applied for the normalisation of the indicator equation (2),

$$
X_{t j=\frac{\operatorname{Max} X_{j}-Y_{t j}}{\operatorname{Max} X_{j}-\operatorname{Min} X_{j}}}
$$

\section{Weighting and Aggregation}

Following normalization, two methods were used to weight the indicators. Initially, equal weightages (1/ number of variables) were attributed to all selected indicators, thus, assuming that all variables had the same value (Hahn et al., 2009; Krishnamurthy et al., 2014). Thereafter, the Principal Component Analysis (PCA) method was used to assign weights to the indicators (Gbetibouo et al., 2010; Ravindranath et al., 2011). Nardo (2008), has provided a detailed description of the use of PCA to generate weights. According to Kaiser Criterion, principal components with eigenvalues greater than 1.0 are suitable for the analysis. These factors were then weighted according to the explained variance divided by the total variance of the selected factors. Next, individual indicators were grouped into intermediate composite indicators. Gbetibouo et al. (2010) and Monterroso et al. (2014) also applied the PCA method to assign a weight, as explained by Nardo (2008). However, they selected only the first principal component, based on the argument that the first component orthogonal linear set of variables has the capability of capturing most of the information common to the other variables (Filmer and Pritchett, 2001; McKenzie, 2005; Labonne et al., 2007).

After weighing each indicator, two methods were used to aggregate the indicators into a single composite index. The first aggregation method was the weighted mean technique used by Ravindranath et al. (2011) equation (3). 


$$
\text { Index Value }=\frac{\sum_{i=1}^{n} w_{j} \times X_{t j}}{\sum_{i=1}^{n} w_{j}}
$$

Where, $w$ is the weight assigned for each indicator and $x$ is the indicator value. Thereafter, the equation below, as used by Gbetibouo et al. (2010) and (Monterroso et al., 2014), was utilized to aggregate the indicators into a vulnerability index.

$$
\text { Index Value }=\sum_{j=1}^{n} w_{j}\left(X_{t j}-\bar{X}_{j}\right) / S_{i} j=1 \ldots \ldots n ; t=1 \ldots . . J(4)
$$

Where, $w$ is the weight assigned for the indicator, $x$ is the indicator value, $\bar{x}$ is the mean indicator value, and $\mathrm{S}$ is the standard deviation of variables. The index values obtained from these aggregation methods were standardized to a range between 0 and 1 for comparative purposes. The index values were then arranged into five categories based on equal intervals (Table 3). Low index values indicate less vulnerability and higher values signal greater vulnerability to climate change.

Table 3: Criteria for vulnerability to climate change based on aggregation method 1

\begin{tabular}{lccccc}
\hline $\begin{array}{l}\text { Vulnerability } \\
\text { index value }\end{array}$ & $0-0.2$ & $0.2-0.4$ & $0.4-0.6$ & $0.6-0.8$ & $0.8-1$ \\
\hline $\begin{array}{l}\text { Severity of } \\
\text { vulnerability }\end{array}$ & $\begin{array}{l}\text { Very } \\
\text { low }\end{array}$ & Low & Moderate & High & $\begin{array}{l}\text { Very } \\
\text { high }\end{array}$ \\
\hline
\end{tabular}

Based on the two weighting methods and two aggregation methods, four vulnerability indices were developed for the analysis of agricultural vulnerability to climate change in Sri Lanka over the chosen period (Table 4).

Table 4: A summary of weighting methods and aggregation methods

\begin{tabular}{llcc}
\hline & & \multicolumn{2}{c}{ Aggregation method } \\
\cline { 3 - 4 } & & $\begin{array}{c}\text { First aggregation } \\
\text { method (equation 3) }\end{array}$ & $\begin{array}{c}\text { Second aggregation } \\
\text { method (equation 4) }\end{array}$ \\
\hline \multirow{2}{*}{$\begin{array}{l}\text { Weighting } \\
\text { method }\end{array}$} & $\begin{array}{l}\text { Equal } \\
\text { Weightage }\end{array}$ & W1A1 & W1A2 \\
& PCA & W2A1 & W2A2 \\
\hline
\end{tabular}




\section{Results and Discussion}

This section summarises the results obtained from the four vulnerability indices. Data availability was a key factor in the development of this vulnerability index. Data were unobtainable for some important indicators reviewed, namely, crop diversification index, amount of area cultivated with high yielding varieties or climate-smart crops, and the number of registered farmer organisations. Gbetibouo et al. (2010) used an infrastructure index as a physical asset under adaptive capacity. For this study, a calculated Infrastructure index was unavailable and, hence one was calculated, based on variables, as chosen and discussed by Gbetibouo et al. (2010). Available data were collected, normalized, and weighted using equal weightage and PCA methods, which were conducted using SPSS. . Three principal components with eigenvalues greater than 1.0 and Varimax rotation technique were selected for the analysis. These three components explained $84.6 \%$ of the total variation in the dataset. Forest area, amount of arable land, population density, unemployment rate, and crop production index required high weightages, and the age dependency ratio and literacy rate, low weights. Some variables were given negative values. Normalized squared factor loadings were calculated using the factor loading matrix obtained after rotation. Weights for each indicator were then assigned accordingly. The index results of the overall vulnerability, calculated using four methods, were then analysed. The results of the data analysis are reported in three parts, based on the study objectives. The first part of the section that follows describes the level of agricultural vulnerability to climate change over the past eighteen years based on the four indices and the factors most contributory to agricultural vulnerability to climate change in Sri Lanka. The second part compares the four methods used to develop the composite indices.

The simple bar chart is one of the most common methods used to illustrate the results of composite indices (Nardo, 2008). Four bar charts were developed based on the four methods used to express the results (Figures 1, 2, 3, and 4). The year was plotted on the horizontal axis and the value of the composite index on the vertical axis. It is apparent that the majority of the vulnerability index values range between 0.4 and 0.6 . The values in the first few years tend towards the 0.4 gridline and in the later years towards the 0.6 gridline. These values signal the potential for increasing vulnerability of Sri Lankan agriculture in future years if no adaptive measures are undertaken. These results are compatible with the findings of the Notre Dame-Global Adaptation (ND-GAIN) Country Index, which rates Sri Lanka's current 
vulnerability at 0.477 on an index ranging from 0 to 1 (higher score means greater vulnerability).

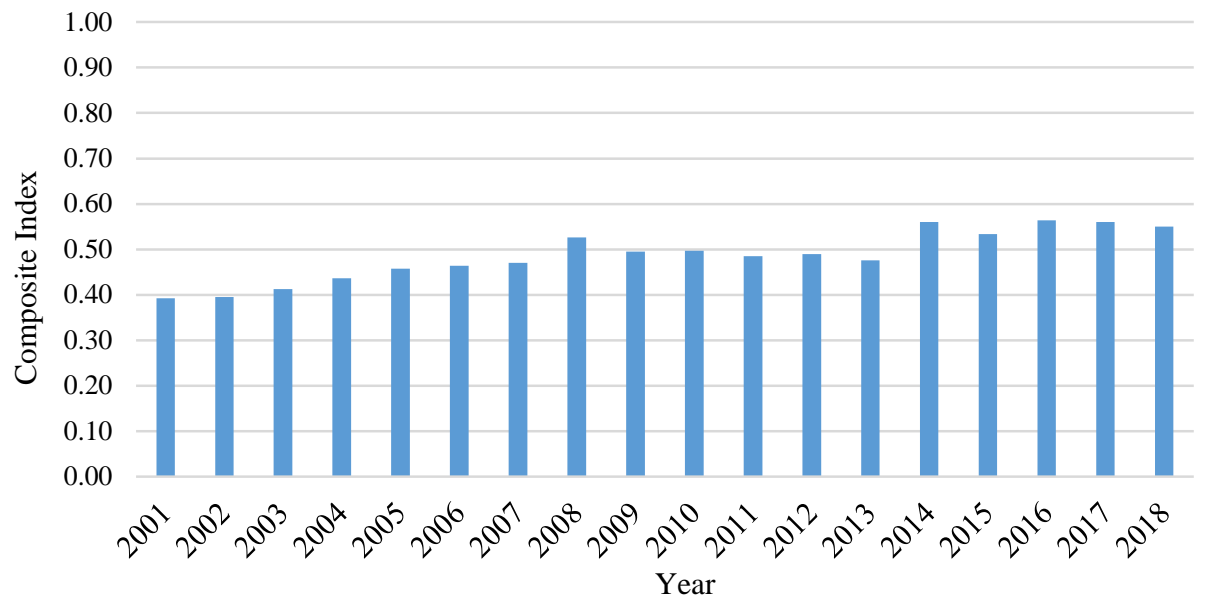

Figure 1: Composite index values of vulnerability: W1A1

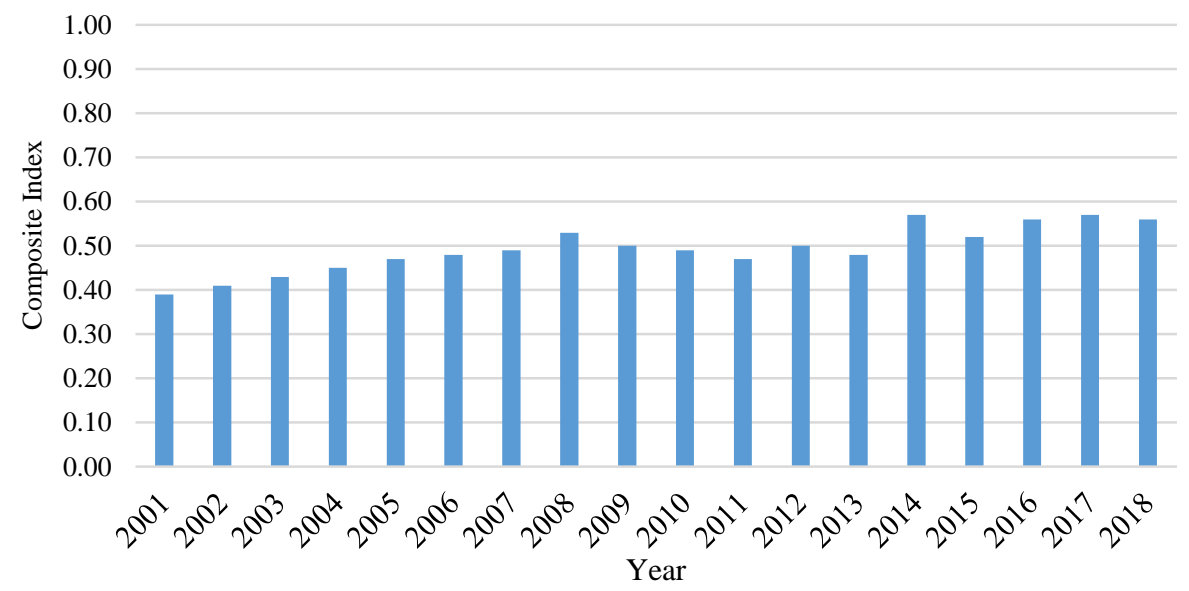

Figure 2: Composite index values of vulnerability: W2A1 


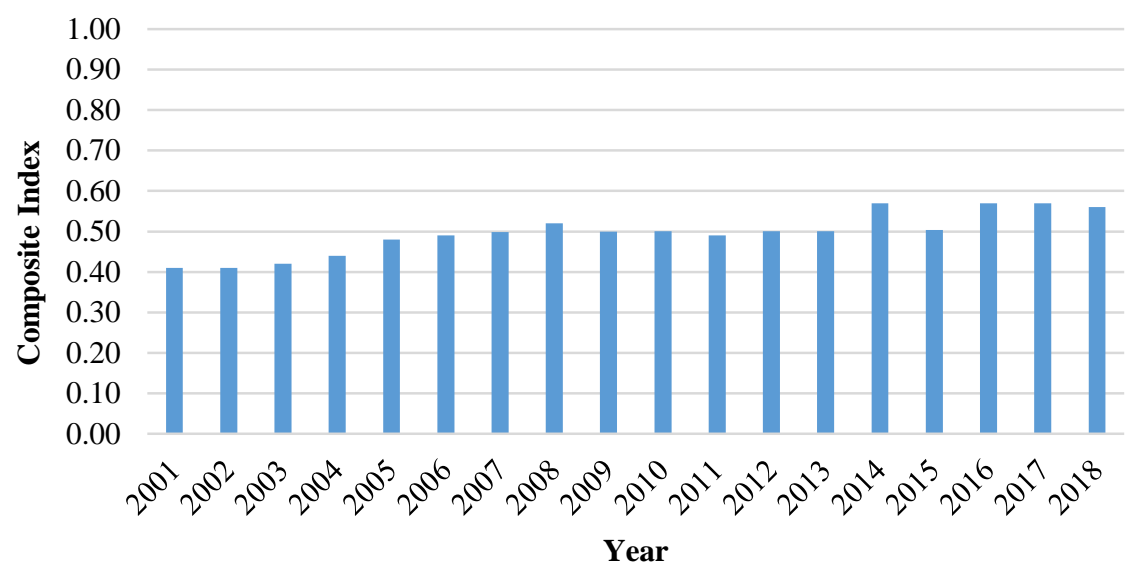

Figure 3: Composite index values of vulnerability: W1A2

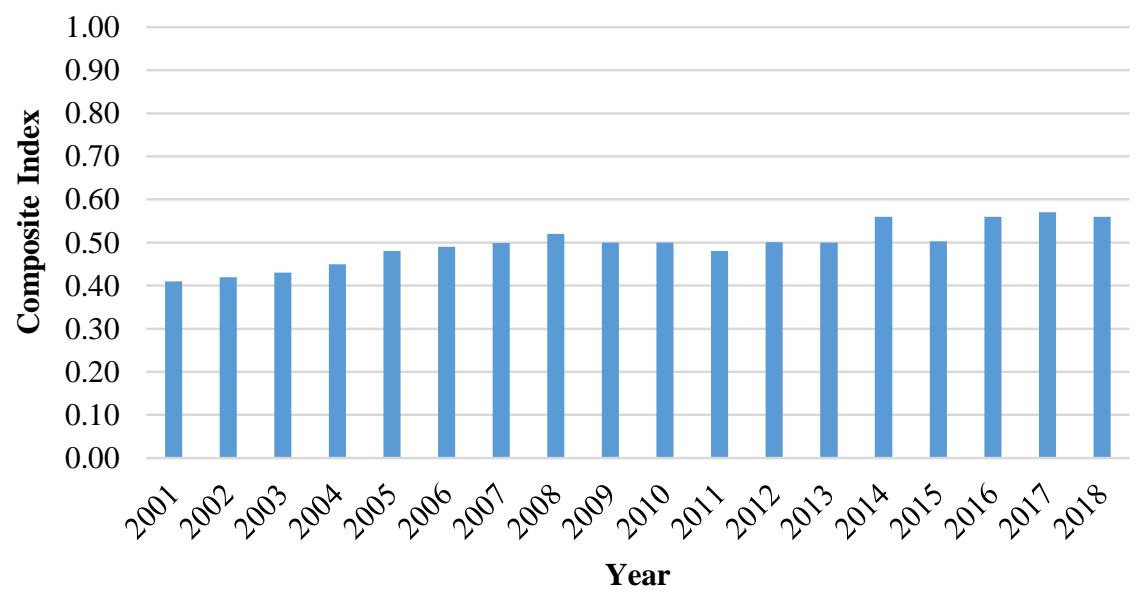

Figure 4: Composite index values of vulnerability: W2A2

For additional insights, the results of the four vulnerability indices were further classified into five vulnerability levels, using equal intervals ranging from very low to very high as explained in Table 3. The results were tabulated into the table below (Table 5) illustrating that the level of agricultural vulnerability in Sri Lanka remained at a moderate level throughout the eighteen-year study period. Alternatively, according to the W1A methods, the vulnerability was at a low level in 2001 , and according to the W2A1 method, the vulnerability was at a low level in 2001 and 2002, thereafter, increasing into the moderate range. 
Table 5: Vulnerability level classification of the four vulnerability indices

\begin{tabular}{|c|c|c|c|c|c|c|c|c|}
\hline \multirow{3}{*}{$\begin{array}{c}\text { Year } \\
2001\end{array}$} & \multicolumn{4}{|c|}{ Aggregation Method 1} & \multicolumn{4}{|c|}{ Aggregation Method 2} \\
\hline & \multicolumn{2}{|c|}{$\begin{array}{c}\text { Equal Weightage } \\
\text { (W1A1) }\end{array}$} & \multicolumn{2}{|c|}{$\begin{array}{c}\text { PCA } \\
\text { (W2A1) }\end{array}$} & \multicolumn{2}{|c|}{$\begin{array}{l}\text { Equal Weightage } \\
\text { (W1A2) }\end{array}$} & \multicolumn{2}{|c|}{$\begin{array}{c}\text { PCA } \\
(\mathrm{W} 2 \mathrm{~A} 2) \\
\end{array}$} \\
\hline & low & 0.39 & low & 0.39 & Moderate & 0.41 & moderate & 0.41 \\
\hline 2002 & low & 0.39 & moderate & 0.41 & Moderate & 0.41 & moderate & 0.42 \\
\hline 2003 & moderate & 0.41 & moderate & 0.43 & Moderate & 0.42 & moderate & 0.43 \\
\hline 2004 & moderate & 0.44 & moderate & 0.45 & Moderate & 0.44 & moderate & 0.45 \\
\hline 2005 & moderate & 0.46 & moderate & 0.47 & Moderate & 0.48 & moderate & 0.48 \\
\hline 2006 & moderate & 0.46 & moderate & 0.48 & Moderate & 0.49 & moderate & 0.49 \\
\hline 2007 & moderate & 0.47 & moderate & 0.49 & Moderate & 0.50 & moderate & 0.50 \\
\hline 2008 & moderate & 0.53 & moderate & 0.53 & Moderate & 0.52 & moderate & 0.52 \\
\hline 2009 & moderate & 0.50 & moderate & 0.50 & Moderate & 0.50 & moderate & 0.50 \\
\hline 2010 & moderate & 0.50 & moderate & 0.49 & Moderate & 0.50 & moderate & 0.50 \\
\hline 2011 & moderate & 0.49 & moderate & 0.47 & Moderate & 0.49 & moderate & 0.48 \\
\hline 2012 & moderate & 0.49 & moderate & 0.50 & Moderate & 0.50 & moderate & 0.50 \\
\hline 2013 & moderate & 0.48 & moderate & 0.48 & Moderate & 0.50 & moderate & 0.50 \\
\hline 2014 & moderate & 0.56 & moderate & 0.57 & Moderate & 0.57 & moderate & 0.56 \\
\hline 2015 & moderate & 0.53 & moderate & 0.52 & Moderate & 0.50 & moderate & 0.50 \\
\hline 2016 & moderate & 0.56 & moderate & 0.56 & Moderate & 0.57 & moderate & 0.56 \\
\hline 2017 & moderate & 0.56 & moderate & 0.57 & Moderate & 0.57 & moderate & 0.57 \\
\hline 2018 & moderate & 0.55 & moderate & 0.56 & Moderate & 0.56 & moderate & 0.56 \\
\hline
\end{tabular}

The results were further analysed using the three dimensions of vulnerability; exposure, sensitivity, and adaptive capacity. The corresponding exposure, sensitivity, and adaptive capacity indexes were calculated separately using equal weightage and weighted mean aggregation methods. The results are displayed in the radar chart below (Figure 5). This type of analysis provides an overview of the levels of factors contributory to vulnerability. The diagram shows an increase in vulnerability due to sensitivity and a corresponding decrease in vulnerability due to adaptive capacity in the later years. From 2001 to 2008 the level of vulnerability due to inadequate adaptive capacity exceeded vulnerability due to sensitivity and exposure. It should be noted that the adaptive capacity of Sri Lanka increased in the later years, thus, reducing its contribution to vulnerability. Additionally, 
vulnerability due to the sensitivity of the system increased, elevating the level of overall agricultural vulnerability to climate change in Sri Lanka.

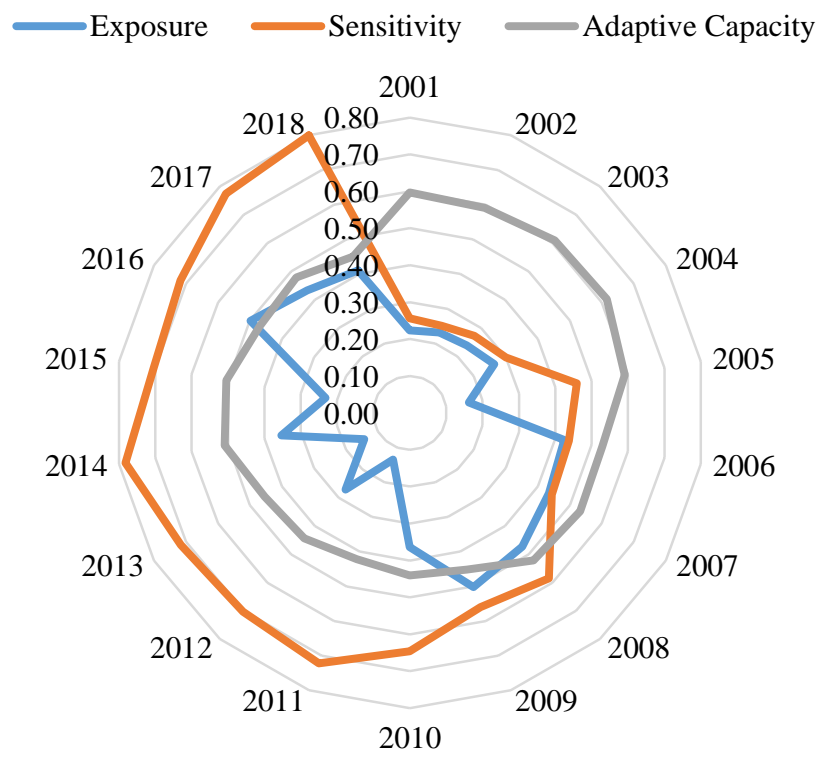

Figure 5: Radar diagram of exposure, sensitivity, and adaptive capacity indices

This analysis facilitates the identification of the factors most influential on increasing levels of vulnerability. It is evident that Sri Lanka should prioritise decreasing the sensitivity of the system to climate change and increasing the adaptive capacity, in order to maintain the current vulnerability level. Additionally, each sub-index can be further analysed to identify the indicators most contributory to vulnerability. Exposure indicators fluctuated over the study period, with the frequency of flood incidents exceeding the frequency of drought and landslide events. However, the trend of increasing temperature and higher exposure to extreme weather events makes Sri Lanka more vulnerable to climate change, as emphasized in the second national communication to the UNFCC submitted by the Ministry of Environment in Sri Lanka in 2012 (Ministry of Mahaweli Development and Environment Sri Lanka, 2016). A lack of forest areas, increasing population, and increasing population density are the major contributors to increasing vulnerability due to sensitivity. These findings compare with those of the World Bank and the Asian Development Bank which indicated that more than two-thirds of the country's forest cover has been removed to accommodate the growing population (The World Bank Group and the Asian Development Bank, 2020). Hence, the government should implement strategies to reduce deforestation and 
enhance reforestation. The age dependency ratio, cost of production of various crops and levels of fertilizer consumption have all shown an increasing trend over the study period and impacted negatively on the adaptive capacity of the country in recent years. The number of university credits dedicated to producing Agriculture graduates annually increased, while the poverty headcount has decreased over the study period, thus, lessening vulnerability in Sri Lanka. All the other variables have shown a fluctuating trend.

A comparison of the four different methods used to develop the indices is also valid. Figure 6 provides a graphical representation of the index values developed based on the two weighting and two aggregation methods. A line chart was used to display the results of four vulnerability indices. It is evident that the different weighing techniques and aggregation methods results have produced slightly different index values. However, it demonstrates the similar linear shape of all four indices. W1A1, W2A1, and W1A2, for example, indicate higher vulnerability values for 2014, 2016, and 2017, while the highest values of the W2A2 index occurred in the year 2017. This confirms the findings of Monterroso et al. (2014). Moreover, 69 out of 72 data points were given similar results in vulnerability level classification. Overall, all the indices illustrate a fluctuating but increasing trend in depicting agricultural vulnerability to climate change in Sri Lanka. Clearly, the government must initiate adaptation strategies to prevent any further increase in the level of vulnerability.

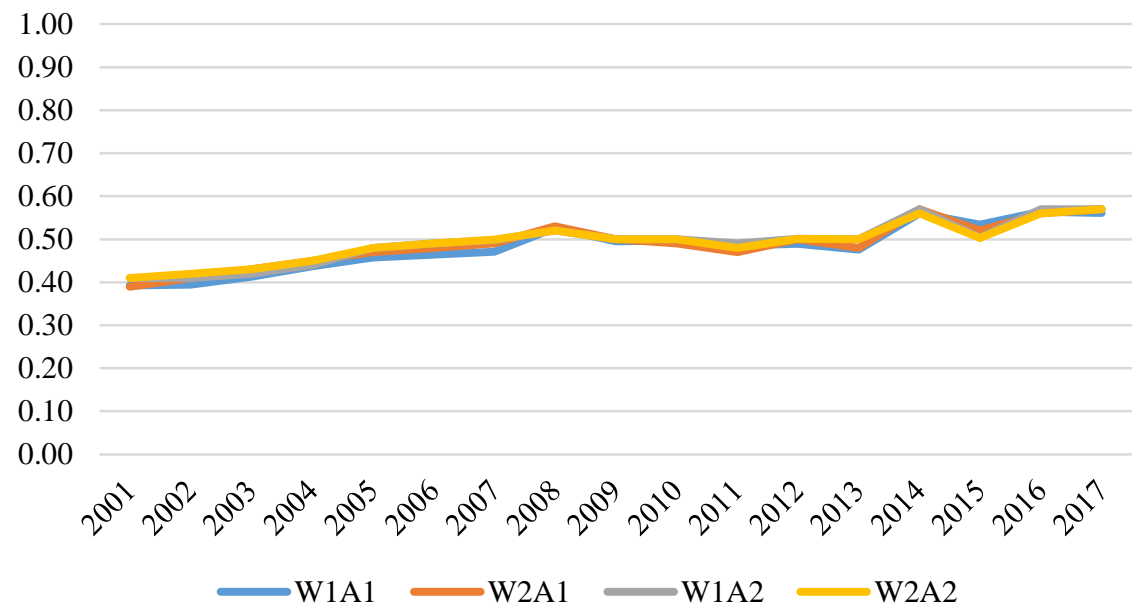

Figure 6: Vulnerability indices based on the four methods 
All the weighting and aggregation methods were easy to calculate. The equal weighting method and weighted mean aggregation methods were easier and quicker. This differed with the findings of Monterroso et al. (2014) who found the PCA method was easier and more suitable for rapid applications than the linear integration (equal weightage) method.

This type of composite vulnerability indices could be used to assess policy outcomes and the impacts of projected strategies. For example, if a strategy aims to increase the irrigation capacity or to increase the crop yield by introducing high-yielding varieties and climate-smart crops, the new expected values can be incorporated to recalculate the index. These attempts would enable the identification of impacts before the strategy implementation. However, it must be mentioned that vulnerability indices have no potential to capture all the direct and indirect impacts of policy interventions and adaptation strategies.

\section{Conclusion}

This study assessed the vulnerability to climate change of the agricultural sector in Sri Lanka, using two weighting methods and two aggregation methods to develop the vulnerability indices. The results of all four vulnerability indices revealed that agricultural vulnerability to climate change in Sri Lanka remains at a moderate level, notwithstanding the increasing trend over the study period. This is trend is due to the sensitivity of the system, despite the increase in adaptive capacity for seventeen years of the study period. The outcome indicates that Sri Lanka should institute additional proper adaptation strategies to mitigate the potential impacts of climate change, particularly measures to reduce its current sensitivity levels. Failure to impose new adaptation strategies could increase the vulnerability in the future, based on the increasing trend in vulnerability illustrated by four indices. Therefore, the urgency to act is great.

In light of the higher frequency of flood incidents reported, the government should construct proper sewerage systems to minimize the environmental impact of flooding. Increasing the irrigation capacity will ensure consistency in water availability to crops. Minimizing deforestation, especially illegal, uncontrolled deforestation, and promoting reforestation will help to increase the forest cover. Strategies to reduce the cost of crop production should be implemented in the agricultural sector. Avoiding over usage of fertilizer would help to minimize production costs. Moreover, an additional budget should be 
allocated to the research and development sector to identify key risk factors and possible adaptation strategies.

Certain limitations of the study need mentioning, as well as suggestions for future research. The scale of the analysis is a key factor in vulnerability assessment. Global, national, regional, and even household-level analyses can be conducted for vulnerability assessments. The choice depends mainly on the purpose of the study. For instance, Krishnamurthy et al. (2014) suggest the smaller-scale analysis for climate change vulnerability assessments. This study focused on the nation-level of Sri Lanka and the scale was appropriate to capture the agricultural vulnerability to climate change of the country. However, it is possible to replicate the same method for a district-level analysis in Sri Lanka. This could be conducted, for example, for the most vulnerable years identified in this study. Depending on data availability, some important indicators such as the amount of land cultivated with climate-smart crops could be incorporated into the index. It is also possible to predict and compare future levels of vulnerability using the indices produced in this study. Predicted values obtained from reliable methods could be used to recalculate the vulnerability indices.

\section{References}

Adger, W. N., Brooks, N., Bentham, G., Agnew, M., \& Eriksen, S. (2005). New indicators of vulnerability and adaptive capacity. Tyndall Centre for Climate Change Research.

Bonan, G. B. (1993). Do biophysics and physiology matter in ecosystem models?. Climatic Change, 24, 281-285.

Brenkert, A. L., \& Malone, E. L. (2005). Modeling vulnerability and resilience to climate change: A case study of India and Indian states. Climatic Change, 72, 57-102.

Brisson, N., Gary, C., Justes, E., Roche, R., Mary, B., Ripoche, D., Zimmer, D., Sierra, J., Bertuzzi, P., \& Burger, P. (2003). An overview of the crop model STICS. European Journal of Agronomy, 18, 309-332.

Brooks, N., Adger, W. N., \& Kelly, P. M. (2005). The determinants of vulnerability and adaptive capacity at the national level and the implications for adaptation. Global Environmental Change, 15, 151-163. 
Clarke, M. L., \& Rendell, H. M. (2010). Climate-driven decrease in erosion in extant Mediterranean badlands. Earth Surface Processes and Landforms, 35, 1281-1288.

Cutter, S. L., \& Finch, C. (2008). Temporal and spatial changes in social vulnerability to natural hazards. Proceedings of the National Academy of Sciences, 105, 2301-2306.

Dale, V. H., Joyce, L. A., Mcnulty, S., Neilson, R. P., Ayres, M. P., Flannigan, M. D., Hanson, P. J., Irland, 1. C., Lugo, A. E., \& Peterson, C. J. (2001). Climate change and forest disturbances: Climate change can affect forests by altering the frequency, intensity, duration, and timing of fire, drought, introduced species, insect and pathogen outbreaks, hurricanes, windstorms, ice storms, or landslides. BioScience, 51, 723-734.

Eakin, H., \& Bojorquez-Tapia, L. A. (2008). Insights into the composition of household vulnerability from multicriteria decision analysis. Global Environmental Change, 18, 112-127.

Eckstein, D., Künzel, V., Schäfer, L., \& Winges, M. (2019). Global climate risk index 2020. https://germanwatch. org/sites/germanwatch. org/files/20-2-01e\% 20Global, 20.

Eriksen, S. H., \& Kelly, P. M. (2007). Developing credible vulnerability indicators for climate adaptation policy assessment. Mitigation and Adaptation Strategies for Global Change, 12, 495-524.

Falloon, P., \& Betts, R. (2010). Climate impacts on European agriculture and water management in the context of adaptation and mitigation-The importance of an integrated approach. Science of the Total Environment, 408, 5667-5687.

Filmer, D., \& Pritchett, L. H. (2001). Estimating wealth effects without expenditure data - or tears: An application to educational enrollments in states of India. Demography, 38, 115-132.

Füssel, H.-M., \& Klein, R. J. (2006). Climate change vulnerability assessments: An evolution of conceptual thinking. Climatic Change, 75, 301-329.

Gbetibouo, G. A., \& Hassan, R. (2005). Measuring the economic impact of climate change on major South African field crops: A Ricardian approach. Global and Planetary Change, 47, 143-152. 
Gbetibouo, G. A., Ringler, C., \& Hassan, R. (2010). Vulnerability of the South African farming sector to climate change and variability: An indicator approach. Natural Resources Forum, Wiley, 175187.

Goodman, D., Watts, M., \& Watts, M. J. (1997). Globalising food: Agrarian questions and global restructuring. Psychology Press.

Hahn, M. B., Riederer, A. M., \& Foster, S. O. (2009). The livelihood vulnerability index: A pragmatic approach to assessing risks from climate variability and change-A case study in Mozambique. Global Environmental Change, 19, 74-88.

Handmer, J. W., Dovers, S., \& Downing, T. E. (1999). Societal vulnerability to climate change and variability. Mitigation and Adaptation Strategies for Global Change, 4, 267-281.

Hansen, M. C., Potapov, P. V., Moore, R., Hancher, M., Turubanova, S., Tyukavina, A., Thau, D., Stehman, S., Goetz, S. \& Loveland, T. R. (2013). High-resolution global maps of 21st-century forest cover change. Science, 342, 850-853.

Hebb, A., \& Mortsch, L. (2007). Floods: Mapping vulnerability in the Upper Thames watershed under a changing climate. Project Report XI, University of Waterloo, 1-53.

Hegglin, E., \& Huggel, C. (2008). An integrated assessment of vulnerability to glacial hazards. Mountain Research and Development, 28, 299-310.

Ionescu, C., Klein, R. J., Hinkel, J., Kumar, K. K., \& Klein, R. (2009). Towards a formal framework of vulnerability to climate change. Environmental Modeling \& Assessment, 14, 1-16.

IPCC. (2001). Climate change 2001: Impacts, adaptation, and vulnerability. Contribution of working group II to the third assessment report of the Intergovernmental Panel on Climate Change. In J. J. McCarthy, O. F. Canziani, N. A. Leary, D. J. Dokken \& K. S. White (Eds.), Cambridge University Press. 
IPCC. (2007). Climate change 2007: Impacts, adaptation and vulnerability. Contribution of working group II to the fourth assessment report of the Intergovernmental Panel on Climate Change. In M. L. Parry, O. F. Canziani, J. P. Palutikof, P. J. Van der Linden \& C. E. Hanson (Eds.), Cambridge University Press.

IPCC. (2014a). AR5 Climate change 2014: Synthesis report. Contribution of working groups I, II and III to the fifth assessment report of the Intergovernmental Panel on Climate Change. Geneva, Switzerland.

IPCC. (2014b). Climate Change 2014: Impacts, adaptation and vulnerability. Contribution of working group II to the fifth assement report of the Global and Sectoral Aspects. Cambridge University Press.

Janssen, M. A., Schoon, M. L., KE, W., \& Börner, K. (2006). Scholarly networks on resilience, vulnerability and adaptation within the human dimensions of global environmental change. Global Environmental Change, 16, 240-252.

Krishnamurthy, P., Lewis, K., \& Choularton, R. (2014). A methodological framework for rapidly assessing the impacts of climate risk on national-level food security through a vulnerability index. Global Environmental Change, 25, 121132.

Kyoto Protocol (1997). United Nations framework convention on climate change. Kyoto Protocol, Kyoto, 19.

Labonne, J., Biller, D., \& Chase, R. (2007). Inequality and relative wealth: Do they matter for trust? Evidence from poor communities in the Philippines. World Bank Social Development Papers.

Lobell, D. B., \& Burke, M. B. (2008). Why are agricultural impacts of climate change so uncertain? The importance of temperature relative to precipitation. Environmental Research Letters, 3(3), 034007.

Lucas, P. L., \& Hilderink, H. B. (2005). Vulnerability concept and its application to food security. RIVM rapport 550015004. 
Luers, A. L., Lobell, D. B., Sklar, L. S., AddamS, C. L., \& Matson, P. A. (2003). A method for quantifying vulnerability, applied to the agricultural system of the Yaqui Valley, Mexico. Global Environmental Change, 13, 255-267.

Masia, S., Sušnik, J., Marras, S., Mereu, S., Spano, D., \& Trabucco, A. (2018). Assessment of irrigated agriculture vulnerability under climate change in Southern Italy. Water, 10, 209.

McCarthy, J. J., Canziani, O. F., Leary, N. A., Dokken, D. J., \& White, K. S. (2001). Climate change 2001: Impacts, adaptation, and vulnerability. Contribution of working group II to the third assessment report of the Intergovernmental Panel on Climate Change, In J. J. McCarthy, O. F. Canziani, N. A. Leary, D. J. Dokken \& K. S. White (Eds.), Cambridge University Press.

McKenzie, D. J. (2005). Measuring inequality with asset indicators. Journal of Population Economics, 18, 229-260.

Ministry of Mahaweli Development and Environment Sri Lanka (2016). Nationally determined contributions. Ministry of Mahaweli Development and Environment Sri Lanka.

Monterroso, A., Conde, C., Gay, C., Gómez, D., \& López, J. (2014). Two methods to assess vulnerability to climate change in the Mexican agricultural sector. Mitigation and Adaptation Strategies for Global Change, 19, 445-461.

Moser, C., \& Satterthwaite, D. (2010). Toward pro-poor adaptation to climate change in the urban centers of low-and middle-income countries. Social dimensions of climate change: Equity and vulnerability in a warming world, 231-258.

Nardo, M. (2008). Handbook on constructing composite indicators methodology and user guide. http://browse.oecdbookshop.org/oecd/pdfs/browseit E, $\underline{3008251 .}$

Nardo, M., Saisana, M., Saltelli, A., Tarantola, S., Hoffman, H., \& Giovannini, E. (2005). Handbook on Constructing Composite Indicators: Methodology and User Guide. Organisation for Economic Cooperation and Development (OECD) [Working Paper JT00188147]. Statistics. OECD. 
Nuñez, L. (2005). Tools for forecasting or warning as well as hazard assessment to reduce the impact of natural disasters on agriculture, forestry and fisheries. Natural Disasters and Extreme Events in Agriculture. Springer.

o'Brien, K., Leichenko, R., Kelkar, U., Venema, H., Aandahl, G., Tompkins, H., Javed, A., Bhadwal, S., Barg, S., \& Nygaard, L. (2004). Mapping vulnerability to multiple stressors: Climate change and globalization in India. Global Environmental Change, 14, 303-313.

Olmos, S., (2001). Vulnerability and adaptation to climate change: concepts, issues, assessment methods. Climate Change Knowledge Network (CCKN).

Olsson, L., Opondo, M., Tschakert, P., Agrawal, A., \& Eriksen, S. E. (2014). Livelihoods and poverty.

Pratley, J. (2008). Workforce planning in agriculture: agricultural education and capacity building at the crossroads. Farm Policy Journal, 5, 27-41.

Ravindranath, N., Rao, S., Sharma, N., Nair, M., Gopalakrishnan, R., Rao, A., Malaviya, S., Tiwari, R., Sagadevan, A., \& Munsi, M. (2011). Climate change vulnerability profiles for North East India. Current Science, 101.

Ribot, J. C. (1995). The causal structure of vulnerability: Its application to climate impact analysis. GeoJournal, 35, 119-122.

Saisana, M., \& Tarantola, S. (2002). State-of-the-art report on current methodologies and practices for composite indicator development, Citeseer.

Schimmelpfennig, D., \& Yohe, G. (1999). Vulnerability of crops to climate change: A practical method of indexing. Global Environmental Change and Agriculture: Assessing the Impacts, In Frisvold \& Kuhn (Eds.), Edward Elgar Publishing Limited., 193-217.

Shah, K. U., Dulal, H. B., Johnson, C., \& Baptiste, A. (2013). Understanding livelihood vulnerability to climate change: Applying the livelihood vulnerability index in Trinidad and Tobago. Geoforum, 47, 125-137. 
Stephen, L., \& Downing, T. E. (2001). Getting the scale right: A comparison of analytical methods for vulnerability assessment and household-level targeting. Disasters, 25, 113-135.

The World Bank Group and The Asian Development Bank. (2020). Climate risk country profile: Sri Lanka. The World Bank Group and The Asian Development Bank.

Vincent, K. (2004). Creating an index of social vulnerability to climate change for Africa (Working Paper). Tyndall Center for Climate Change Research, 56.

Watson, R. (2000) Climate change, 2000 [Conference Presentation]. The Sixth Conference of Parties to the United Nations Framework Convention on Climate Change, 2000.

Wiréhn, L., Danielsson, A., \& Neset, T. S. S. (2015). Assessment of composite index methods for agricultural vulnerability to climate change. Journal of environmental management, 156, 7080 .

Yusuf, A. A., \& Francisco, H. (2009). Climate change vulnerability mapping for Southeast Asia. IDRC. https://idl-bncidrc.dspacedirect.org/handle/10625/46380.

Zhang, X., \& Cai, X. (2011). Climate change impacts on global agricultural land availability. Environmental Research Letters, 6,014014 . 